\title{
Public land management: New mandate for the land grant university?
}

Henry Vaux

Associate Vice President for Programs

Today's urbanized society no longer views natural resources primarily as commodities for extraction. There is growing concern for developing sustainable, healthy life styles from the land base; there is increasing controversy about the effects of agriculture on the management of natural resources, and public lands in particular.

California's natural resources emanate from a rich and diverse land base of 100 million acres. Of that land, less than $20 \%$ has been completely converted to human use, whether for cultivated farmland or urban and suburban development. More than 80 million acres are to some degree "natural lands," including 40 million acres used for grazing, 12 million in parks and reserves, and 17 million in productive forest available for timber harvest.

A recent report from the Western Council of Administrative Heads of Agriculture (CAHA) Committee on Public Lands raises new issues for land use and natural resource management. The report observes:

In the past few decades, the majority of people expressing interest in public lands shifted from those producing a commercial product to those interested in amenities, recreation and environmental protection. Many new users charge that land grant universities are not devoting enough effort to public lands and even when they are, they are addressing only the issues of interest to commodity producers.

The report, "Managing Transitions: Western Agricultural Colleges and Public Lands," later states:

If land grant universities are successful in identifying what society expects from its public lands and apply the land grant model to new issues, they can be as effective today as they were in changing America from a country of rural poor to the well fed industrial power of the 20th century.

Authored by Thadis Box, currently the Gerald Thomas Professor in Food Production and Natural Resources at New Mexico State University and formerly the Dean, College of Natural Resources, Utah State University, the report asserts that agricultural colleges have focused too narrowly on production agriculture. Box recommends that land grant universities apply their expertise to the role of the public lands in the sustainable health of all communities. In this manner, the land grant university can connect to new, vital constituencies.

"Embracing new constituencies does not mean abandoning old and traditional clientele," Box says. This is particularly true in California, where farming and related activities generate about $10 \%$ of the gross state product. California agriculture is an $\$ 18$ billion industry. The food and fiber system creates, directly and indirectly, nearly one in ten jobs in the state.

Given the robust, diversified nature of California's agricultural industry, what lessons can be drawn from the Thadis Box report? In view of the crucial role agriculture plays in the state's economy, UC has an obligation to help sustain its pro- ductivity. However, productivity no longer means maximum outputs per unit of input; it means obtaining sustainable, profitable yields while adapting to new constraints on resource use and traditional agricultural practices.

The UC Rangeland Watershed Program is one example of how UC faculty and specialists are serving traditional clientele in new ways. Cattle grazing along streams and waterways can damage delicate habitats, threatening the survival of other plants and animals and causing erosion that sweeps soil into spawning areas downstream. With help from a $\$ 500,000$ grant from the Environmental Protection Agency, Cooperative Extension advisors and specialists are developing new management practices to protect rangeland ecology.

UC faculty are playing an increasing role in the resolution of environmental concerns. UC's Wildland Resources Center has identified 840 academic staff in 161 departments on 8 campuses and 44 county offices who are involved in some aspect of California's wildlands and natural resource conservation and management.

The challenge to maintain agricultural vitality while protecting natural resources calls for an interdisciplinary effort. Specialists in production agriculture, geographers, biologists who study species habitat and ecosystem dynamics, public policy experts, economists and land managers must combine their resources to develop sound, research-based information.

An example of UC playing an integrative role of this kind is the Sierra Nevada Mountain Range ecosystem study. Funded by a $\$ 7$ million U.S. Forest Service grant, UC scientists will oversee a scientific panel performing a detailed scientific assessment of the Sierra Nevada ecosystem, integrating knowledge on the biological, physical and socio-economic environments of the region. The panel will develop a range of options for conserving the full variety of life in the region's ecosystem while providing resources to meet human needs.

The outcome of such research will be of value to all with interests in the management of California lands including commodity producers. More work is needed to address other major issues listed in the CAHA report: allocation and balance of multiple land uses; the condition of rangelands and forests; economic viability of public land ranching; endangered species management; fair rental value for forage; riparian area management; and water quality, rights and management.

In addition, UC scientists and researchers must explore cooperative relationships with their counterparts in state and federal agencies. What research, education and training is needed to complement existing state and federal efforts?

UC's academic faculty, specialists and advisors are positioned to develop broad contact with diverse publics involved in natural resource issues. If the Division can meet the needs of new constituencies in a transformed New West, and apply what it learns, it will lead nationally in the enlightened use of natural resources - both for the benefit of agriculture, and to meet the environmental needs of the urban public. 